\author{
А. С. Кулева
}

Институт русского языка им. В. В. Виноградова РАН

(Россия, Москва)

an_kuleva@mail.ru

\title{
МНИМЫЕ НЕОЛОГИЗМЫ В ПОЭТИЧЕСКОМ ЯЗЫКЕ (НА МАТЕРИАЛЕ VII ТОМА «СЛОВАРЯ ЯЗЫКА РУССКОЙ ПОЭЗИИ ХХ ВЕКА»)
}

«Словарь языка русской поэзии XX века», отражающий поэтический язык Серебряного века на примере произведений десяти выдающихся авторов (Анненский, Axматова, Блок, Есенин, Кузмин, Мандельштам, Маяковский, Пастернак, Хлебников, Цветаева), содержит, наряду с общеупотребительной лексикой, и лексику индивидуально-авторскую. В ряде случаев это авторские неологизмы, отмечаемые пометой нов., т.е. «новое». Нередко это потенциальные слова, образованные по регулярным моделям, которые могли быть заново созданы конкретным автором в конкретном случае, но могли и воспроизводиться. Однако более интересны слова, которые выглядят как неологизмы, но оказываются устаревшими или областными, а также пограничные случаи - лексемы, которые совпадают с реально существующими, но употребляются в новом значении. Проверить сделанные наблюдения на более широком материале позволяет обращение к поэтическому подкорпусу НКРЯ. Таким образом, привлекает внимание не только авторское словотворчество, но и его средства и механизмы - пути создания нового поэтического слова. В статье представлены некоторые наблюдения из опыта работы над словарем. Используется материал VII тома (Радуга - Смоковница. М., 2017; более 5 тыс. словарных статей).

Ключевые слова: авторская лексикография, корпус, лексикология, лингвистическая поэтика, неологизм, поэтический язык.

Неология в поэтическом языке - явление важное и хорошо изученное [Григорьев 1986]. Однако не менее интересны случаи «мнимых» неологизмов — когда на первый взгляд читателю кажется, что то или иное слово придумано автором (а некоторые читатели такие слова склонны считать или чересчур манерными, или почти бессмысленными), тогда как это лексические единицы устаревшие, областные, взятые из других языков и др. Например: райна (устар. 'рея (сущ.)'), рень (др.рус. 'отмель, низкий берег’), реун (обл. 'сентябрь'), рясный (устар. 'украшенный 
подвесками'), самокат (устар. 'автомобиль'), самота (укр. ‘одиночество'), свичадо (польск. 'зеркало') и др.

«Словарь языка русской поэзии XX века», отражающий поэтический язык Серебряного века на примере произведений десяти выдающихся авторов (Анненский, Ахматова, Блок, Есенин, Кузмин, Мандельштам, Маяковский, Пастернак, Хлебников, Цветаева), содержит, наряду с общеупотребительной лексикой, и лексику индивидуально-авторскую. В СЯРП помета нов. приписывается разным типам слов: ее назначение - привлечь внимание к нестандартному словоупотреблению в поэтическом тексте. Так, в материале VII тома (Радуга - Смоковница. М., 2017; более 5 тыс. словарных статей) помета нов. сопровождает 148 слов на букву Р и 172 на С.

Сравним примеры (в словарных статьях из названного тома СЯРП используются условные обозначения Словаря - шифры, указывающие на автора и год создания произведения (Анн - Анненский, $A x м$ - Ахматова, $A D$ - Блок, $E c-$ Есенин, Куз - Кузмин, $O M$ - Мандельштам, $M$ - Маяковский, $П-$ Пастернак, Хл Хлебников, Цв - Цветаева), РП - речь персонажа).

Индивидуально-авторские лексемы очень разнообразны. С одной стороны, это слова, сознательно созданные автором, в предельном случае - которые читатель без подсказки автора может и не понять:

РАУМ [нов.; «не знающий границ, преград, лучистый, сияющий ум. Речи его раречи»] [Зангези:] <..> Миум. Р.. Хоум. Хаум. Бейте в благовест ума! Вот колокол и веревка. РП Хл920-22 (482.3); Соум. Поум. Глаум. Р.. Ноум. Нуум. Выум. Бом! РП Хл920-22 (483).

С другой стороны, это вполне прозрачные слова: окказионализмы, созданные по регулярным моделям, которые могли быть заново созданы конкретным автором в конкретном случае, но могли и воспроизводиться. К разряду «новой», индивидуально-авторской лексики могут быть отнесены и потенциальные единицы, создаваемые по регулярным моделям (розоватить, сверхжизненный). Наличие таких слов в других источниках (в частности в толковых словарях русского языка [Ушаков; БАС; МАС] и [НКРЯ]) не говорит однозначно о том, что слово не было «придумано» поэтом: если оно было создано как авторский неологизм в соответствии с законами языка, оно может воссоздаваться заново. Однако и в лексемах, отмечаемых словарной пометой нов., интересно проследить связь с фактами и тенденциями языка. И наоборот: в отдельных случаях материал НКРЯ дает основания отказаться от признания слова неологизмом.

Наиболее интересны промежуточные случаи, когда слово кажется вполне понятным, но оказывается неупотребительным; или наоборот: слово представляется неологизмом, или даже некой авторской вычурностью, но его можно найти в других источниках - в словарях и в НКРЯ. Т. е. слово явно выступает как индивидуально-авторское, но при этом может быть обнаружено в языке - и здесь остается гадать, было ли оно прообразом для поэтической новации, или языковое чутье поэта воссоздало языковую единицу, причем иногда в совершенно другом значении (в СЯРП в ряде случаев добавляется информация через «сравни»). 
САМОЗВАНЧЕСКИЙ [нов.] Пред самозванческим указом Нежности - Что наши доблести и родословные! // С какой торжественною постепенностью Спадают выспренные обветшалости! О наши прадедовы драгоценности Под самозванческим ударом Жалости! Цв921 (II,23.2); ср. в НКРЯ: Новой династии и классам, на которые она опиралась, духовенству и дворянству, земский собор был нужен, пока земля не оправилась от самозванческой встряски: по мере успокоения слабела и правительственная нужда в соборе [В.О. Ключевский. Русская история. Полный курс лекций. (1904)].

СВЕРЛИВЫЙ [нов.] И вот, / как ристалищный конь, / ринешься взрывом вод, / взъяришься, храпишь, мечешь / мокрый огонь / на белое небо, рушась и руша, / сверливой воронкой буравя / свои же недра! [о море] Куз917 (184); ср. в НКРЯ: При людях была она бессловесна, а дома, возле маиньки и приживалок, зла и сверлива, как буравчик [Ф.М. Достоевский. Скверный анекдот (1862)].

СВЕТОПИСЬ [нов.; $с$.: устар. получение изображений с помощью оптического аппарата на основе действия света на светочувствительные вещества; фотография] - Остановись, С. зорких стрел! В тайнописи любви Небо - какой пробел! Цв922 (II,126); ср. в НКРЯ: Скончавшийся и тот, кто жив, - То - светопись и негатив! [К.К. Случевский. Загробные песни. 2. (1902)]; Авиатором пилота, самолет - аэропланом, даже светописью - фото звали в том столетьи славном [Б. А. Слуцкий. Затесавшееся столетье (1971-1977)].

Особенно интересно сопоставление лексем одного гнезда - однокоренных слов или слов, образованных по схожим моделям.

РАЗАГИТИРОВАТЬ [разг.] Я вот что скажу / (пришипился в шепоте, / ей [Эйфелевой башне] / в радиоухо / шепчу, / жужжу): / — Я разагитировал вещи и здания. / Мы — / только согласия вашего ждем. / Башня — / хотите возглавить восстание? / Башня — / мы / вас выбираем вождем! M923 (106).

РАЗБУКЕТИТЬСЯ [нов.] Разбукетилось небо к вечеру, Замерзло окно... Не надо весеннего ветра, Мне и так хорошо. Куз917 (193.2).

РАЗГВОЗДИТЬ [обл.; расклинить, забить клин, гвоздь] Все равно - он иным отелится Солнцем в наш русский кров. // Все равно - он спалит телением, Что ковало реке брега. Разгвоздят мировое кипение Золотые его рога. Ec918 (II,37); ср. два примера ХХ в. в НКРЯ (Горький и Лавренев): Что же, к примеру, если мой батька в пьяном виде башку об стенку разгвоздил, так и я тоже обязана бабахаться? [Б. А. Лавренев. Сорок первый (1924)].

РАЗДОРОЖИЕ [ср. обл. раздорожье (место, где расходятся дороги, распутье)] Дабы могильного поверх горба: «Единой Верности была раба!» На раздорожии, ребром к столбу, Богиня Верности - распни рабу! Цв921 (II,63.2); РАЗДОРОЖНЫЙ [прил. к раздорожье] Там где во поле, во пустом Воронье да волк, Становись надо мной крестом, Р. столб! Цв916 (I,276.1); У раздорожного креста Раскрыл глазочки. Цв921 (II,71.1).

РАЗЬЯРИТЕЛЬНИЦА [нов.] Ты, срывающая покров С катафалков и с колыбелей, Р. ветров, Насылательница метелей, // Лихорадок, стихов 
и войн, - Чернокнижница! - Крепостница! - [обращ. к А. А. Ахматовой] Цв916 (I,307.1).

РАСПЛАТЧИК [нов.] И бурчало / у трущоб в утробе, / покрывая / детвориный плачик: / — Под работу, / под винтовку ль, / на́ — / ладони обе! / Приходи, / заступник / и р.! - РП М924 (459).

РАССИРОПИТь [нов.] В духовках солнца / горы́ / жарко́е. / Воздух / цветы рассиропили. / Наши / с песней / идут от Джанкоя, / сыпятся / с Симферополя. M927 (581); ср. два примера ХІХ в. в НКРЯ (Гончаров и Писемский): Антип Ильич, рассиропив рейнвейн водой и всыпав в стакан огромное количество сахару, покончил с болем и после того тотчас раскраснелся в лице, как маков иявет [А.Ф. Писемский. Масоны (1880)].

СВЕРХБЕССМЫСЛЕННЕЙШИЙ [нов.] - Завтра с западу встанет солНце! — С Иего́вой порвет Давид! — Что мы делаем? - Расстаемся. — Ничего мне не говорит // Сверхбессмысленнейшее слово: Рас — стаемся. - Одна из ста? Просто слово в четыре слога, За которыми пустота. Цв924 (III,43).

СВЕРХЖИЗНЕННЫЙ Может быть, это точка безумия, Может быть, это совесть твоя - Узел жизни, в котором мы узнаны И развязаны для бытия. // Так соборы кристаллов сверхжизненных Добросовестный свет-паучок, Распуская на ребра, их сызнова Собирает в единый пучок. OM937 (249); ср. пять примеров в НКРЯ, из них три - более ранние, чем контекст Мандельштама (дважды Чуковский (1905), Шишков (1928-1933), а также Набоков (1940-1942), Кенжеев (2007)): Но когда признала, она впала в другую крайность: она захотела непременно верить, что те отвлеченные сверхжизненные положения, которые созданы ибсенизмом, поддаются конкретному, осязательному выражению [К.И. Чуковский. «Маленький Эйольф» Ибсена (1905)].

СВЕРХСТАВКА [нов.] Я хочу, / чтоб над мыслью / времен комиссар / с приказанием нависал. / Я хочу, / чтоб сверхставками спе́ца / получало / любовищу сердце. $M 925$ (235).

От приведенных примеров отличаются лексические единицы другого рода.

РАСПРИ [«р.»; возм., вар. к ЭСПРИ] На улицу вышел — / глаза разопри! / В каждой витрине / буржуевы обноски: / какая-нибудь / шляпа / с пером «распри», / и туфли / показывают / лакированные носики. Ирон. M927 (309); ср. эспри 'украшение в виде пера или пучка перьев, расходящихся в разные стороны, которое прикалывается к женской прическе или женскому головному убору' [БАС] и pacnepemь (рифма: глаза разопри).

РЫБОКРЫЛ [сущ..; нов.; возм., пингвин] О, Сад, Сад! <..> Где смешные рыбокрылы заботятся друг о друге с трогательностью старосветских помещиков Гоголя. [о зверинце] Хл909,11 (185); ср. представленные в словарях лексемы: винтокрыл, иерстокрыл, бескрыл.

СИВЕНЬ [нов.] [Зангези:] Слушайте! Верхарня серых гор. Бегава вод в долину, И бьюга водопада об утесы Седыми бивнями волны. И сивни облаков, Нетоты туч Над хивнями травы. РП Хл920-22 (487); ср.: обл. сивень 'сентябрь'. 
Также привлекают внимание нестандартные грамматические формы, которые попадают в фокус зрения, поскольку в СЯРП такие формы выносятся в отдельную словарную статью:

- краткая форма и формы степеней сравнения:

РАЗНОЧИНЕН [кр. ф. прил. разночинный; нов.] Все разночинно, наспех, какнибудь... Отцы и деды непонятны. Земли Заложены. И в Бадене - рулетка. Ахм945 (253.1).

РАЗЛУЧЁННЕЙ [нов.] Не придумать разлуку бездонней, Лучше б сразу тогда - наповал... И, наверное, нас р. В этом мире никто не бывал. Ахм963 (226.1).

РАСПЛАСТАННЕЙШИЙ [нов.] — Не властвовать! Без слов и на́ слово Любить... Распластаннейшей В мире - ласточкой! Цв922 (II, 130).

- причастия и деепричастия:

РАССКАЛЬЗЫВАЮЩИЙСЯ [нов.] Расскальзывающаяся артиллерия Тарелями ластится к отзывам ветра. П914,28 (I,63).

РАЗМОЗОЛЕВ [нов.] А оказывается — / прежде чем начнет петься, / долго ходят, р. от брожения, / и тихо барахтается в тине сердца / глупая вобла воображения. M914-15 (393).

РАЗМОЗОЛИВАЯ [нов.] о, какой / невероятной топкой / сердце Маркс / и мысль свою зажег! / Будто сам / в заводе каждом / стоя сто́ймя, / будто / каждый труд / р. лично, / грабящих / прибавочную стоимость / за руку / поймал с поличным. M924 (466).

- нестандартные притяжательные формы, как и краткие действительные причастия, в особенности характерные для Маяковского:

СЕНОВ [нов.; прил. к СЕНА] Быть Сены полосе б Невой! / Грядущих лет брызго́й / хожу по мгле по Се́новой / всей нынчести изгой. M923 (440).

СЕНСКИЙ [нов.; прил. к СЕНА] Рассвет. / Подымаюсь сенскою сенью, / синематографской серой тенью. / Вот - / гимназистом смотрел их / с парты - / мелькают сбоку Франции карты. М923 (442.1).

СЛЕПЯЩ [нов.] Испанский камень / с. и бел, / а стены — / зубьями пил. / Пароход / до двенадцати / уголь ел / и пресную воду пил. $M 925$ (172).

Поиски «корней» слова никак не умаляют роли словотворчества в поэтическом языке. Лексикографирование таких единиц позволяет обратить на них более пристальное внимание, проследить укорененность в языке поэтических неологизмов, отметить тонкие семантические особенности индивидуальных употреблений [Шестакова 2011].

\section{Литература}

БАС - Словарь современного русского литературного языка. Т. 1-17. М.; Л.: Изд-во АН СССР, 1948-1965.

Григорьев В. П. Словотворчество и смежные проблемы языка поэта. М.: Наука, 1986. $255 \mathrm{c}$. 
МАС - Евгеньева А. П. (ред.). Словарь русского языка. Т. 1-4. М.: Гос. изд-во иностранных и национальных словарей, 1957-1960.

HКРЯ - Национальный корпус русского языка [Электронный ресурс]. URL: http:// www.ruscorpora.ru.

СЯРП - Словарь языка русской поэзии XX века. Т. I-VII-/ Григорьев В. П. (отв. ред.), Шестакова Л.Л. (отв. ред.), Колодяжная Л.И. (ред.), Кулева А.С. (ред.), Бакеркина В. В., Гик А. В., Реутт Т.Е., Фатеева Н. А. М.: Языки славянской культуры, Знак, 2001-2017-.

Ушаков - Толковый словарь русского языка. Т. 1-4 / Под ред. Д. Н. Ушакова. М.: ОГИЗ, 1935-1940.

Шестакова Л. Л. Русская авторская лексикография: Теория, история, современность. М.: Языки славянских культур, 2011. 464 с.

\section{A.S. Kuleva}

V.V. Vinogradov Russian Language Institute of the Russian Academy of Sciences (Russia, Moscow) an_kuleva@mail.ru

\section{SEMI-NEOLOGISMS IN THE POETIC LANGUAGE: ON THE MATERIAL OF THE VII VOLUME OF THE «DICTIONARY OF THE LANGUAGE OF THE XX CENTURY RUSSIAN POETRY»}

The paper highlights the work on the VII volume of the «Dictionary of the Language of the XX Century Russian Poetry». The multivolume summary (Moscow, 2001, 2003, 2008, 2010, 2013, 2015, 2017; by ten poets: Annensky, Akhmatova, Blok, Yesenin, Kuzmin, Mandelstam, Mayakovsky, Pasternak, Khlebnikov, Tsvetaeva) demonstrates lexical structure of the language of Silver Age poetry — one of the most important periods in the development of Russian literature and culture. In the article author's neologisms often used in the poetry are analyzed. It is showed that among such words obsolete, colloquial, dialectal lexemes may be noted as the basis for creation of author's neologisms.

Key words: author lexicography, corpus, lexicology, linguistic poetics, neologism, poetic language.

\section{References}

Grigor'ev V.P. Slovotvorchestvo i smezhnye problemy yazyka poeta [Word creation and adjacent problems of poetic language]. Moscow, Nauka Publ., 1986. 255 p.

Natsional'nyi korpus russkogo yazyka [Russian National Corpus]. Available at: http:// www.ruscorpora.ru.

Shestakova L.L. Russkaya avtorskaya leksikografiya: teoriya, istoriya, sovremennost'. [Russian author lexicography: theory, history, modernity]. Moscow, Yazyki Slavyanskoi Kul'tury Publ., 2011. 464 p. 
Slovar' russkogo yazyka [The dictionary of the Russian language]. Evgen'eva A.P. (ed.). Vol. 1-4. Moscow: Gosudarstvennoe Isdatel'stvo Inostrannykh I Natsional'nykh Slovarei Publ., 1957-1961.

Slovar' sovremennogo russkogo literaturnogo yazyka [A dictionary of modern standard Russian]. Vol. 1-17. Moscow, Academy of Sciences of the USSR Publ., 1948-1965. Slovar' yazyka russkoi poezii XX veka [Dictionary of the Language of the XX Century Russian Poetry]. Grigor'ev V.P., Shestakova L.L., Kolodyazhnaya L.I., Kuleva A. S., Bakerkina V.V., Gik A.V., Reutt T.E., Fateeva N. A. (eds.). Vol. I-VII-. Moscow, Yazyki Slavyanskoi Kul'tury Publ., Znak Publ., 2001-2017-.

Ushakov D. N. (ed.). Tolkovyi slovar' russkogo yazyka [Explanatory dictionary of the Russian language]. Vol. 1-4. Moscow, OGIZ, 1935-1940. 